\title{
THE ANALYSIS OF CREDIT FINANCING OF HOME OWNERSHIP WITH MURABAHAH AT PT. BANK SYARIAH MANDIRI PALEMBANG
}

\author{
Muhammad Fahmi, Popy Febrina \\ Muhammadiyah University of Palembang
}

\begin{abstract}
The purpose of this study was to find out whether the housing loan financing (mortgage) at Bank Syariah Mandiri Palembang Branch in accordance with murabaha and to know the process of granting mortgage with murabahah scheme in Bank Syariah Mandiri Branch Palembang to prospective recipients of financing. The research method used was descriptive method that was by collecting the data obtained and then interpret and analyze so as to provide information that can be used to solve the problems encountered. The data used were primary data and secondary data. The results of this study indicate mortgage loans at PT. Bank Syariah Mandiri has been in accordance with the murabahah financing agreement and analysis on PSAK No. 102 concerning Murabahah as the basis of consideration of the Conformity of House Ownership Credit at Bank Syariah Mandiri Palembang Branch Office.
\end{abstract}

Keywords: Financing, Home Ownership Credit , Akad Murabahah 


\section{INTRODUCTION}

Islamic banks use schemes Murabaha to provide short-term financing to its clients (customers) to buy goods even though the client (the customer) may not have the cash to pay. Murabahah, as used in Islamic banking, is found primarily based on two elements, namely the purchase price, the associated price and the Mark-up (profit) agreement .

Companies that will be analyzed in this study is the PT Bank Syariah Mandiri branch office in Palembang. PT Bank Syariah Mandiri gave Murabahah financing services, in the form of investment financing, working capital financing and consumer financing. One of the consumptive financing is the Housing Loan Financing or The Mortgage Loan in the framework of buying houses, shophouses, flats / apartments for individual customers during the period of financing, the amount of fixed installment and it is not changed until fully paid.

Here is the calculation of financing and annuity margin calculation on the credit home owners PT.Bank Syariah Mandiri and comparison of several other Islamic banks regarding margin calculation:

Table 1

Murabaha With Margin Annuity

\begin{tabular}{|c|c|c|c|c|c|c|c|}
\hline No & Loan Amount & $\begin{array}{l}\text { Down Pay- } \\
\text { ment }\end{array}$ & Bank Financing & Timeframe & Margin Annuity & $\begin{array}{l}\text { Monthly } \\
\text { Installment }\end{array}$ & Total Financing \\
\hline 1 & 500.000 .00 & 180.000.00 & 320.000 .000 & $5^{\text {th }}$ & $12.50 \%$ & 7.199 .340 & 431.960 .400 \\
\hline 2 & $500,000,000$ & 180.000.00 & 320.000 .000 & 10th & $13.50 \%$ & 4.872 .777 & 584.733 .240 \\
\hline 3 & $500,000,000$ & 180.000 .00 & 320.000 .00 & $15^{\text {th }}$ & $14.50 \%$ & 4.369 .603 & 786.528 .540 \\
\hline
\end{tabular}

Source: PT.Bank Syariah Mandiri KC Palembang , 2014

Based on the data observation on the table 1 above and interviews conducted by researchers that in reality the specified margin is highly visible even though the monthly installment is unchanged or fixed and does not affect the interest rate fluctuations. Based on the above comparison results in table 1 and table 2 on the comparison of margin calculation and financing between Bank Syariah Mandiri and other syariah Bank. Bank Syariah Mandiri are sharia banks that have lower margin amount compared to other sharia banks. However, at the point of light installments and fixed to maturity, the financing we should consider is the difference in the total nominal amount from the period prior to the end of the credit term expires.

Although The monthly installments sharia higher margins and unchanged or fixed and does not affect the interest rate fluctuations, but in fact margins are set appear larger value than the conventional one. Here 's its calculations :

Table 2

Calculation of KPR Financing Bank Central Asia

\begin{tabular}{|c|c|c|c|c|c|c|c|}
\hline No & Loan Amount & $\begin{array}{l}\text { Down Pay- } \\
\text { ment }\end{array}$ & Bank Financing & Timeframe & Margin Annuity & $\begin{array}{l}\text { Monthly } \\
\text { Installment }\end{array}$ & Total Financing \\
\hline 1 & 500.000 .00 & 180.000 .00 & 345 million & $5^{\text {th }}$ & $10.00 \%$ & $6,799,054$ & 407943.240 \\
\hline 2 & 500,000,000 & 180.000 .00 & 345 million & 10th & $12.00 \%$ & 5.162 .718 & 550.928 .400 \\
\hline 3 & 500,000,000 & 180.000 .00 & 345.000 .00 & $15^{\text {th }}$ & $12.00 \%$ & $4,699,842$ & 691.296 .840 \\
\hline
\end{tabular}

Source: PT. Bank Central Asia 
Figure 1

Fine Calculations Late Payment

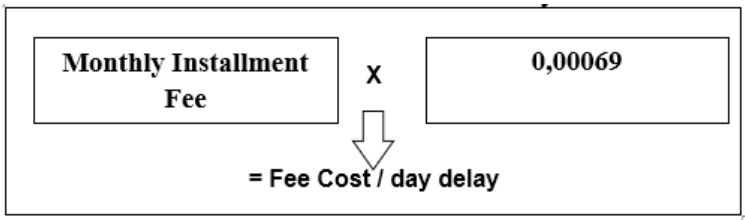

Source: PT.Bank Syariah Mandiri KC Palembang

Based on the next observation we can see in Figure 1 above on the point about the light and fixed installment until the maturity of the financing that we must pay attention is the fact that Bank Syariah Mandiri impose a late fee for Murabaha financing on mortgage loans.

Here is the data obtained regarding the amount of disbursement in the year 2012-2014 which experiencing an increase per year following the amount of disbursement of funds at PT. Bank Syariah Mandiri:

\begin{tabular}{ccc}
\multicolumn{3}{c}{ Table 3 } \\
\multicolumn{3}{c}{$\begin{array}{c}\text { Fund Disbursement Data } \\
\text { PT Bank Syariah Mandiri }\end{array}$} \\
\hline Year of Disbursement & NOA & Nominal \\
\hline 2012 & 52 & Rp. 14,866,720,000 \\
\hline 2013 & 201 & Rp. 60.439.439.00 \\
\hline 2014 & 398 & Rp. 87.695.177.000 \\
\hline
\end{tabular}

Source: PT Bank Syariah Mandiri KC Palembang

The above table is the amount of disbursement made by Bank Syariah Mandiri during the year 2012-2014. In Bank Syariah Mandiri there are also customers who are classified as stuck or categorized in collectibility 5 ( Non Perfoming Fund ), Bank Syariah Mandiri set 3\% maximum non-performing loans in the company, calculated not from the number of customers but $3 \%$ of the total financing ceiling. In 2014 there are 1 -2 customers categorized in bad credit .

Despite the existence of collateral but these customers are being categorized as bad due to the inability of customers to pay installments that have exceeded maturity up to 272 days for the bank to follow up on the delay of the customer in paying the installment. Based on the description above the author intends to conduct research studies entitled "The Analysis of Credit Financing of Home Ownership With Murabahah at PT.Bank Syariah Mandiri Palembang Branch Office”

\section{LITERATURE REVIEW}

- Akad Murabahah

Murabahah bi tsaman ajil or better known as Murabahah this word comes from the word ribhu (profit) is a sale and purchase transactions where the bank mentions the amount of profit.. The bank or sharia institution acts as the seller, while the customer acts as the buyer. The selling price is the purchase price of the bank from the supplier plus the profit, both parties must agree on the selling price and the timeframe for the payment. The sale price is included in the trading agreement and if it has been agreed, it can not change during the contract. In murabahah banking is usually done by installment payment (bi tsaman ajil). In this transaction the goods are delivered immediately after the contract while the payment is done on a tough basis.

PSAK 102 , Murabahah is a sale and purchase of goods at the selling price of the acquisition cost plus the agreed profit and the seller must disclose the cost of the item to the buyer. Sales can be made in cash or credit (Payout is tough).

In the murabaha agreement, different rates are permitted for different payment methods. For example, cash price, price tough with a period of 1 year or 2 years is different. But the seller and the buyer must have the price agreed upon in the contract and once agreed upon then there is only one price (the price in the contract) used and this price can not be changed. If the purchase repays faster 
than the specified credit period or the buyer postpones the payment, the price shall not change.

The seller may request a down payment on the buyer as proof of his seriousness to purchase the item. The down payment becomes part of the settlement of murabahah receivables if the murabahah agreement is agreed. But if the seller buys the goods and the buyer cancels them, this advance may be used to cover the seller's losses due to the cancellation of the order. If the amount of down payment is less than the amount of loss the seller must bear, the seller may request a shortage of money to the buyer. Conversely, if the greater the buyer is entitled to take or receive back some of his face money.

If the sales contract is deferred and buyers can not pay it off in a timely manner or even he repaid faster than a predetermined period, the seller must give the piece. However, the magnitude of this discount should not be promised at the beginning of the contract (to avoid any element of usury).

If the buyer can not repay the debt within the stipulated time, the seller is not allowed to impose a penalty on the buyer's delay because the overpayment of a debt equals usury. Exceptions apply, if the buyer does not pay not because of financial difficulties but because of negligence. In this case the imposition of a fine is allowed.

Figure 2

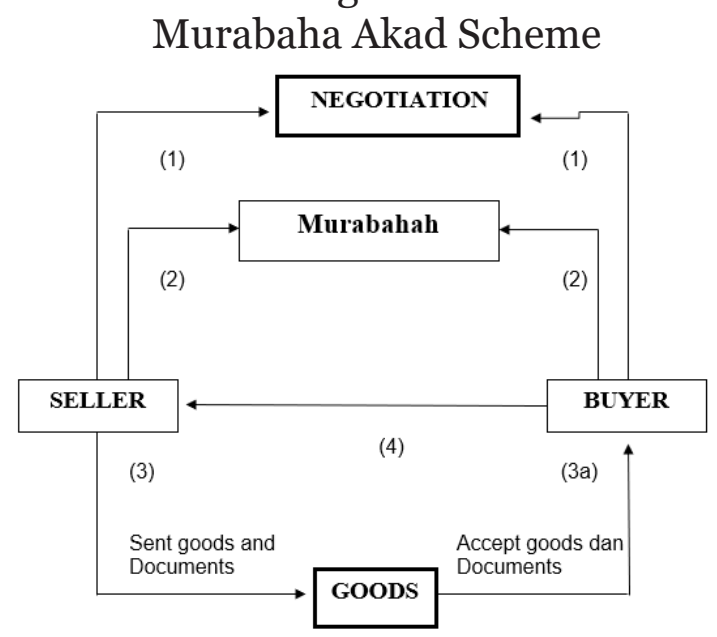

Source : H Veitzhel (2008 :147)

\section{RESEARCH METHODS}

The data used by the authors in this study is the primary data and secondary data where in this study the data obtained, obtained through interviews to employees of the credit granting and financing of Bank Syariah Mandiri House Ownership.

In this research, the data analysis used by the writer is qualitative method of qualitative, murabahah qualitative method that is analyzing the financing of Sharia House Ownership Credit with Murabahah Akad starting from the beginning of contract (agreeing the agreement that has been determined) until the end of the contract (paid off or default). Doing the deal begins the transaction is absolutely necessary for the transaction to feel sharia.

\section{RESEARCH RESULT}

\section{Bank Syariah Mandiri Housing Credit Financing Process \\ a. Financing products}

Financing with Murabahah Akad

Murabahah financing is a buying and selling agreement between a bank and a customer in which the bank buys the required item and sells it to the respective customer at the acquisition cost plus the agreed benefit between the customer and the bank. The payment can be made in cash or later on a date that has been agreed.

According of interview result at Bank Syariah Mandiri that The using of a Murabaha Agreement only for its consumer products for the home stay nice new house or old house, shop and four-wheeled vehicles.

Financing Griya Bank Syariah Mandiri is already there and is still ongoing. But there are some special provisions for prospective customers about the calculation of the percentage of down 
payment required to customers by type of house are as follows:

\begin{tabular}{llll} 
& \multicolumn{2}{c}{$\begin{array}{c}\text { Table } 4 \\
\text { Type and Percentage } \\
\text { Griya Bank Syariah Mandiri }\end{array}$} \\
\hline Home Type & $\begin{array}{l}\text { Down pay- } \\
\text { ment Home } \\
\text { First }\end{array}$ & $\begin{array}{l}\text { Down pay- } \\
\text { ment Home } \\
\text { Second }\end{array}$ & $\begin{array}{l}\text { Down pay- } \\
\text { ment Home } \\
\text { Third }\end{array}$ \\
\hline $\begin{array}{l}<70 \text { square } \\
\text { meters }\end{array}$ & $10 \%$ & $30 \%$ & $40 \%$ \\
\hline $\begin{array}{l}\text { = 70 square } \\
\text { meters }\end{array}$ & $20 \%$ & $30 \%$ & $40 \%$ \\
\hline $\begin{array}{l}>70 \text { square } \\
\text { meters }\end{array}$ & $30 \%$ & $40 \%$ & $50 \%$ \\
\hline
\end{tabular}

Source: Bank Syariah Mandiri Palembang Branch Office, 2014.

\section{b. Process and financing flow of Home Ownership Credit}

From the interview result of the researcher at Bank Syariah Mandiri Palembang Branch Office that the process and the flow of Peili Credit Credit House starts from the following stages:

Figure 3

Process / Flow of customer financing at Bank Syariah Mandiri KC Palembang

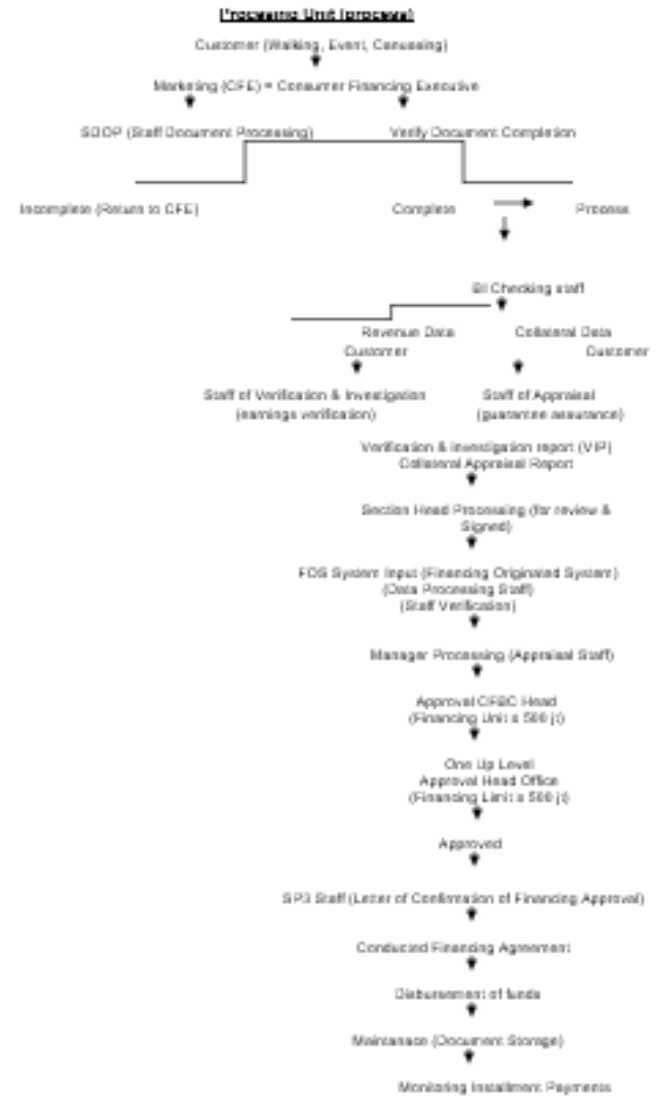

2. Implementation of Home Ownership Credit with Murabaha Akad at Bank Syariah Mandiri

a. Picture of House Ownership Loan at Bank Syariah Mandiri Palembang Branch Office

Based on interviews researchers found that the amount of margin is set by agreement between the customer and Bank Syariah Mandiri Cabang Palembang following is an agreed amount of margin the number of Bank Syariah Mandiri:

1) Margin 1 - 5 years at $12.50 \%$.

2) Margin 6 - 10 years of $13.50 \%$.

3) And Margin 11 - 15 years of 14, 5 o \% .

In this financing is usually the bank has been working with the developers as a supplier (provider of house) so that customers pay a down payment (urbun) directly to the developer for the new home and former homes. In terms of financing request and fulfillment of the terms of the House Ownership Loan customers aided by the developer, but if customers can also manage their own application for financing. For more details, the author explains and details how the recognition and measurement of financial transactions the House Ownership Loan on Syariah Mandiri Cabang Palembang, which can be seen from the following calculation example:

On August 1, 2014, Sulayman applied for a purchase of a new house type> 70m ${ }^{2}$ with Rp. 500.000.000, - where Sulaiman pays a down payment of $30 \%$ (Rp 180.000.000, -) to the bank, after the bank makes an assessment of the request Sulaiman has the ability to repay for 10 years (120 months). The Bank agrees to take a profit margin of $13,50 \%$ / year. The translation of financing calculation is as follows:

House price: Rp. 500.000.000, Down payment: Rp. 180.000.000, - 
The value of financing: Rp.

320.000.000, -

Margin $=13.50 \% \times 10 \times \mathrm{Rp}$.

320.000.000, - = Rp. 432.000.000, -

Margin Month = Rp. 432.000.000, -

$120=$ Rp. 3.600.000, -

The procedure of giving the financing in Bank Syariah Mandiri implies a fee that is directly paid by the customer when the contract lasts. The costs are

1. Administration fee of $1 \%$ of financing

2. The cost of life insurance and a $s$ uransi fires magnitude depending on the age of customers.

3. Tax of Customs Behind the Name (BBN)

4. The cost of binding that will require collateral in the form of Letter of Property (SHM) of the house purchased.

\section{b. Griya Requirement for Credit} of Bank Syariah Mandiri House Ownership Palembang Branch .

Feature requirements for employee employee / employee are as follows:

1) Employee status with regular income.

2) Indonesian citizens are proficient in law.

3) Minimum age 21 years old and maximum 55 years old at maturity date.

4) Maximum financing $100 \%$ of the estimated price of homeowned Home Loan Housing.

5) Having savings Bank Syariah Mandiri.

6) Clients discover by life insurance financing plus layoffs.

Features General requirements:

1) WNI proficient law.

2) Minimum age 21 years old and maximum 55 years old at maturity date.

3) Maximum financing $70 \%$ of house purchase price.
4) The installment does not exceed $40 \%$ of net monthly income.

Payment Features:

1) The installment remains until the payment period remains.

2) Easy and fast application process.

3) Flexible to buy new or used houses.

4) Maximum financing ceiling up to 5 billion.

5) Long-term financing period.

6) Autodebet facility from savings Bank Syariah Mandiri.

Required documents :

1) Photocopy of Applicant's Identity Card.

2) Copy of Family Card.

3) Photocopy of married letter (when married).

4) Original s lip salary and job description.

5) Photocopy of savings / current account last 3 months.

6) Copy of NPWP for financing above Rp.50.000.000

7) Fotoc opy account phone and electricity.

\section{c. Bank Syariah Mandiri House Ownership Loan Agreement}

Bank Syariah Mandiri House Ownership Loan using Murabahah agreement (Akad) on its financing, which is guided by PSAK No. 102 about Murabaha, where the bank specifies the amount of profit, when the bank acts as a seller while the customer acts as a buyer. After all credit proposals are approved by the company, the last step is to do the Akad, here is the process of credit agreement at Bank Syariah Mandiri:

1) Presence of Customers, Bank Syariah Mandiri Party and Seller as witnesses.

2) The Presence of Husband and Wife (when married).

3) The Bank will read the Letter of Confirmation on the Agreement Agreement (SP3) which contains 
all matters concerned with nominal credit and others as follows: Defi nition Akad Murabaha, Advertising, Forms of financing, fines and compensation, term of financing, Realization murabaha, Tempo settlement of the purchase, Jamin's financing, insurance collateral, Life insurance, fees and taxes, Implementation of the account, the Power bank at as account the financing recipient, the right of the bank to terminate the term of financing, the limited restriction on the actions of the beneficiary, the Default, the legal domicile.

4) If Customer agrees with $\mathrm{SP}_{3}$ that has been read by Staff Pel. Akad then, the customer is expected to sign the documents that exist.

5) Setelah does Financing Agreement, the parties shall make disbursements of funds baak.

\section{Credit}

\section{a. Credit Analysis}

Credit is a risky business, where there is a possibility of credit being given uncollectible (bad credit). The debtor can present a million reasons for that. On the other hand the bank must still pay every rupiah of public funds placed on it. Whatever happens to the credit, banks should not not pay public funds.

In connection with this, banks should only provide credit (loans) to the eligible debitor. The bank must be able to control the credit risk it provides. To that end, the bank developed a selection process to screen every prosposal of incoming loans. Through the screening process is expected to give credit is a good quality according to the results of the analysis of the author about the credit stages are good and true, the authors provide an overview derived from Jopie Jusuf book (2008) as a reference for good and correct credit stages, The Process in general that is; Credit Proposal Credit Analyst - Documentation - Fund Disbursement - Credit Monitoring.

Each credit proposal will be carefully analyzed. When eligible, newly held documentation (binding of credit and guarantees). Although the credit analysis of a proposal is declared feasible, but if in the bundle of credit / collateral there are problems that can not be resolved and / mebahayakan bank, the credit must be stopped.

a. Bad Debts at Bank Syariah Mandiri Palembang Branch .

Based on interviews researchers found that set a maximum percentage limit for the size of bad loans to companies, Bank Syariah Mandiri set up 3\% for the category of Non Perfoming Fund which is calculated not from the number of customers but from the amount of financing ceiling of the house ownership fund .

\section{b. Bank Syariah Mandiri Regulation concerning Credit Jam warning letter}

There are 3 warning letters given to customers who Late or delinquent in installment payment:

1) First Warning Letter (SP 1)

Is a letter that will be given to customers who have been late paying installments up to maturity passing from 1 month.

2) Second Warning Letter (SP 2)

Is a letter that will be given to customers who have been late to pay the installment with maturity of 3 months.

3) Third Warning Letter (SP 3)

Is a letter that will be given to customers who have been late to pay installments with maturities of over 5 months.

Based on the interview result of the writer that The disbursement that if the bank has given the Warning Letter to 
the customer / debtor up to $\mathrm{SP}_{3}$ (3rd warning letter), but the customer / debtor still does not pay the installment then the bank will issue the policy and make affirmation to the customer / debtor for continuation payment.

c. Settlement of Bad Debts at Bank Syariah Mandiri.

If the confirmation letter that has been sent to the customer has reached the third warning letter yet the customer has not take action to pay the jam installment from interview result that Bank Syariah Mandiri will do some of the following stages:

1) Restructurisation

Restructuring is matters that include changes in organizational structure, management, operations, systems, and procedures, finances, assets, debt, and so on. Conducted for rescue credit as well as saving the debtor's business to return to health (Accounting Guidelines for Indonesian Banking, revision 2001) Restructuring conducted among others:

a. Decrease in interest rates.

b. Extend credit period.

c. Reduction of arrears principal interest.

d. Reduced arrears principal.

e. Added credit facility.

f. Conversion of loans into temporary equity.

2) Novation

Novation is a business done by the bank in the renewal of customer debt jammed, by giving waivers to customers for the amount of monthly installment so that customers can start repaying installments on the company.

3) Auction

Auction is the final settlement of bad credit in Bank Syariah Mandiri House Ownership Credit, if the customer can not resolve his bad credit problem even if the bank has done the
Restructuring or Novasi then by this auction the Bank will Auction House Customer through third party, in accordance with the price and amount of the remaining credit of the house.

\section{Credit Financing Analysis}

Credit financing analysis is a very determining factor for low interest to know the amount of interest or margin that will be used for the perception of the customer / debtor in choosing the bank that will be the objective, to avoid Losses due to the inability of customers to return the loan as well as interest expense or default or credit stalled, the customer will also be affected by the burden that must be paid that can threaten the life of the company further (going concern), therefore the importance of analyzing the financing to be performed by the customer.The purpose of this shariah credit financing analysis is to identify the conformity of sharia credit financing with the Financial Accounting Standards Regulations implemented in the company. To run a good credit financing, Then the conformity of the company must be contained in accordance with PSAK / Regulation of Financial Accounting Standards. 102 about Murabaha.

\section{a. Margin Calculation}

Based on theanalysis of authors of Bank Syariah Mandiri take advantage based on Murabaha on ALCO (Asset Liability Comitee) results so the percentage has been set and so does the bid limit. But this also can change if associated with APR (Account Profitability Ratio) .

In Murabaha this uses the calculation of profit by the method of effective calculation or equivalent to 1.79 times the calculation of flat margins. If it says $10 \%$ flat margin then it is equivalent to $17.9 \%$ effective margin .

Effective margin calculation is the calculation of margin taking based on outstanding or also called the remaining 
principal to be paid, while the calculation of flat margin is the calculation of margin taken from the given ceiling. The margin of effective margin is as follows:

Debt principal $=\mathrm{Rp} . \mathbf{1 , 0 0 0 , 0 0 0}$

Effective margins per month $=1 \%$

Monthly Basic Installment $=100,000$

So in the 1st month margin to be paid by customers amounting to Rp.1.000.00o $\mathrm{x} 1 \%=\mathrm{Rp} \cdot 10,000$.

In the second month the customer must pay a margin of RP. $900.000 \times 1 \%=$ Rp.9.000

As for the calculation of Margin flat: in month 1 the customer pays Rp. 100,000

in other month the customer still pay Rp. 100,000 due to the calculation of the ceiling given $1.000 .000 \times 1 \%$.

At a glance the calculation is the same as the interest but very different between interest and margin because the calculation is only a tool used to measure how much profit to be obtained by Bank Syariah but the agreement still buy-sale agreement and not borrow and borrow and after the contract will no longer change the price because it is the contract of sale and purchase, therefore the aggregation in Sharia Bank will remain from the beginning until the completion of credit .

\section{Financing Process Analysis}

\section{a. Calculation of Financing}

Results Analysis of researchers that there is PT. Bank Syariah Mandiri for the preparation stage of financing the staff of the officer's part of the company has done a good survey, but there is bad debt in 2014. The preparation stage of financing is the beginning stage with the intention to know each other basic information between the prospective customer and the company, especially in the prospective customer who first time which will be applying for credit will usually do the initial interview.

In this case, the Verification \&
Investor Staff section will verify the client's income if in then Appraisal Staff will impose warranties, for it is in this process should be done survey obtained directly so that applications are completely accurate and consistent with the fact that its application is feasible or not to approve for avoiding the troubled loans to the company.

In this transaction process murabahah financing the bank acts like a seller then the bank does not have inventory which is the assets of the company. For the bank to distinguish between the assets with the purpose of sale and not for sale, assets for the purpose of resale in the form of murabahah recognized as murabahah assets, the recognition of murabahah assets are as follows:

a) Murabahah with the order binding

1) Rated as cost and recorded by journal as follows: Inventory / Murabahah asset $\quad$ xxx Advances to suppliers $\quad \mathrm{xxx}$ Cash / account / clearing $\mathrm{xxx}$

2) Should there be any impairment in value of assets due to obsolescence, damages, or other conditions, they shall be recognized as an expense and reduced to the assets and recorded by the following journal: Loss of murabaha stock loss xxx Murabaha stock xxx

b) Murabaha without order or murabahah based on non binding order:

1) Assessed which is lower between cost or net realizable value.

2) If the net realizable value is less than the cost, the difference is recognized as liabilities $n$.

At the time of the contract, the murabahah receivables are recognized to be less than the cost of acquisition plus the agreed profit and at the end of the period, the receivables are valued 
at the realizable value of the amount of the murabahah receivables less the receipt of doubtful accounts. The profits derived from murabahah financing can be acknowledged:

1) On acquisition, if the contract on the same financial statements.

2) During the proportional contract period, if it exceeds the limit of one reporting period.

At the time of purchase of the asset for sale, the bank may obtain a discount from the supplier. Therefore, the purchase discount from the supplier is recognized as a deduction of the cost, whereas for deductions at the time of redemption can be recognized using one of the following methods:

a) If a deduction is granted upon completion, the bank reduces murabahah and profit receivables, the journal:

Cash XXX

Murabaha margin is suspended xxx

Murabaha margin receivables xxx

Murabahah receivables xxx

b) If the deduction is granted after the settlement, the receivable bank receives the receivable, then the bank pays the deduction (deducting the profit), with the journals made there are two namely:

(1) Cash $\mathrm{xxx}$ Murabaha margin is suspended xxx

Income margin murabaha $\quad \mathrm{xxx}$ Murabahah receivables $\quad \mathrm{xxx}$

(2) Load cuts $\mathrm{XXX}$

$\mathrm{K}$ as

XXX

For customers who do not comply with and fulfill their obligations in accordance with an agreed contract, the bank may impose penalties on the customer. Upon receipt, fine recognized as part of social funds, its journals are:

Cash / accounts $\quad \mathrm{xxx}$

Account of virtuefund $\quad \mathrm{xxx}$

In buying and selling, the bank allows thecustomer to pay a deposit or sign when signing an initial booking agreement. The down payment or signature is the amount paid by the subscriber indicating he or she is serious about the order. In sharia bank advances are also referred to as Urbun. acknowledgment and measurement urbun are:

a) Urbun is recognized as a deposit of the amount received by the bank upon receipt, the journal is:

Cash / accounts $\quad \mathrm{xxx}$ Your money deposit / buyer (urbun) $\quad \mathrm{xxx}$

b) When the finished goods are purchased by the customer, urbun is recognized as a receivable payment, the journal is:

Ticket deposit $\quad \mathrm{xxx}$

Murabahah receivables $\quad \mathrm{xxx}$

c) If the canceled item is purchased by the customer, the urbun returned to the customer is calculated with the expenses incurred by his journals bank are:

Paying deposit of pe mbeli ( urbun) Xxx

Cost $\quad \mathrm{xxx}$

Cash / accounts $\quad \mathrm{xxx}$

\section{b. Late Charge}

In SFAS No. 102 revised 2013 in paragraph 5 says that if the buyer or the customer can not repay the debt within the stipulated time, the seller or the bank may not impose a penalty on the buyer's delay because the overpayment of a debt equals usury.

Based on the interview result of the researcher that Bank Syariah Mandiri impose late fees to customers who are late to pay the due installment with the amount of monthly installment fee $\mathrm{x}$ $0.00069 \%=$ total cost of the delay per 
day.

After the authors do an analysis of the problem of the cost of penalty installment fee is that Bank Syariah Mandiri charges a late fee for social donation, but based on the author's analysis with reference to PSAK No.102 Murabaha it is not allowed to impose a late fee penalty, Social and for the benefit of Bank Syariah Mandiri itself in Murabahah Bank as the seller is not allowed to impose a late fee penalty to the customer / buyer.

Moreover, if the buyer is unable to pay the installment due to financial difficulties Murabaha prohibits his imposition of fines due to the happening of usury on the financing except in case the customer is well off but negligent in financing installment until maturity then the imposition of fine is allowed.

\section{Bad Credit Analysis}

\section{a. The customer profession of Sharia Bank House Ownership Credit}

In this financing, Bank Syariah Mandiri does not specify customers who work as Civil Servants (PNS) and Bank Syariah Mandiri does not specify payroll customers using Bank Syariah Mandiri payroll to become its customers in House Ownership Credit. For that following some types of professions become customers of Bank Syariah Mandiri Financing Loans:

1) Civil Servants (PNS)

2) Private employees

a)Entrepreneur of contractor company

b) Land producers

c) Restorant Entrepreneur

d) Employers of Service Companies

e) Health worker

From some of the above professions who become customers for Credi House Ownership in Bank Syariah Mandiri Branch of Palembang, no doubt for the occurrence of bad credit or misfire occurs because in addition to payments do not use the payroll system and the merit of customers is a private employee, but Bank Syariah Mandiri use collateral from customers for as collateral . However, if Bank Syariah Mandiri has used the Customer's Collateral as a Guarantee the possibility of collateral guarantee is greater than the amount of financing that has been given to the customer, but in the year 2014 recorded customer approximately 1-2 customers are in the category of bad loans. And the possibility of an auction if the customer has not yet paid installment payment to the bank.

\section{b. Results of Analysis s Credit stuck}

The stages of classification of bad debts is the result of continuous monitoring by officer officers because officer staff is required to conduct proper supervision and as well as possible so that the other customers are not in the same circumstances.

Based on the interview result of the researcher, the reason for the occurrence of bad credit this time is due to the customer who is given the financing of his profession as an entrepreneur with unfinished income so that the bad credit in the second year (two) and the bank can not predict whether the next year will happen the delay

Therefore, this customer has been categorized in category 5 and Bank Syariah Mandiri is doing several stages in order to solve the problem to the customer so that the history of customer installment can be recovered and can be repaid as before, but despite the existence of collateral which become guarantee but this customer will continue to do the stages that have been described previously for the relationship of customers who have reached the Colif. 5.

Will still do its auction for home customers that what if after bank restructuring and nofas i to customers 
then the Bank is already doing and have provided relief to the customer but not any possible solution to this problem the bank will still conduct the auction.

There is no error in the procedures or monitoring mistakes made by the Bank Syariah Mandiri, but because the customer is a self-employed entrepreneur who is in trouble in financing in the second year due to the unstable earnings resulting in delinquent installments of mortgage loans that have been overdue and more of 272 days which have been categorized as collectible 5 or Nonperforming Loans that the company suffers from operational loss.

\section{CONCLUSIONS AND RECOMMENDATIONS Conclusions}

Based on the above research results it can be concluded that:

1. Bank Syariah Mandiri Palembang Branch is one of the businesses engaged in the distribution of Consumer Funds that are not all in accordance with A kad Murabahah in PSAK No. 102, especially on Financing Fines.

2. The process of mortgage financing (KPR) in Bank Syariah Mandiri Palembang Branch has been fully Using scheme or Murabahah process .

3. Bank Syariah Mandiri treatment against Credit (mortgages) are jammed in Bank Syariah Mandiri Palembang Branch has been very good and follow the corresponding provisions B ank I ndonesia about bad loans.

\section{Recommendations}

1. In the process of providing mortgage financing (KPR) more improved again the principle of fairness for consumers to fully comply with Akad Murabah ah .

2. For further research, we can further examine the comparison of mortgage financing in sharia banks in Indonesia.

\section{BIBLIOGRAPHY}

Andrea Pemata Veithzal, H. Veithzal Rivai. 2008 . Islamic Financial Management : Teori Konsep, dan Aplikasi : Panduan Praktis Untuk Lembaga Keuangan, Nasabah, Praktisi dan Mahasiswa, PT.Raja Grafindo Persada, Jakarta Utara.

Fatwa Dewan syariah Nasional. 2000. Nomor $\quad$ 04/SDN-MUI/IV/2000. IAI.2007. PSAK NO. 102 Tentang akuntansi Murabahah. Jakarta.

Harahap, Sofyan Syafri, Wiroso dan M.yusuf. 2004 . Akuntansi Perbankan Syariah, penerbit LPFE USAKTI. Jakarta.

Ikatan Akuntan Indonesia . 2009. Persyaratan Standar Akuntansi Keuangan. Edisi Revisi . Jakarta; Salemba Empat.

Jopie Jusuf, 2008, Analisis Kredit untuk Accont Officer, PT. Gramedia Pustaka Utama, Jakarta.

Muhammad,2005, Pengantar Akutansi Syariah, Edisi Revisi, Jilid Dua, PT. Salemba Empat, Jakarta.

Nur Indianto dan Bambang Supomo .2009 . Metode Penelitian bisnis . BPFE Yogyakarta.

Sugiyono. 2009 . Metode Penelitian Bisnis. Cetakan ke-13 Alfabeta, Bandung.

Warkum sumitro. Asas-Asas Perbankan Islam Dan Lembaga-Lembaga Terkait (BAMUI,takaul Dan Pasar). PT Raja Grafido persada. 2004. Modal syariah di Indonesia.

Yusuf Qardhawi. Norma dan etika Ekonomi islam. Pent . Zainal Arifin dan Dahlia Husin Jakarta : Gema Insani.

http://www.bcasyariah.co.id/produk/ pembiayaan/simulasi/\#simulasiangsuran-murabahah. 
Hasanuddin Economics and Business Review

Vol. 2 No. 3 (215-227)

http://www.syariahbukopin.co.id/

simulasi

www.BankSyariahMandiri.co.id 